\title{
Being an Italian Medical Student During the COVID-19 Outbreak
}

Nicolo G. Biavardi.

\section{The Experience}

Many students around the world have been wondering how their life will change since the very first outbreak of COVID-19. I am Italian. I am from Milan. I am into the storm. Said plainly, I had never imagined that my life as a medical student could have changed as such. Since February 21St 2020, when the first case of COVID-19 was recorded in Italy, the National Healthcare Service, which offers universal access to healthcare, has faced increasing pressure, with 73780 total cases of COVID-19 and 6801 deaths as of March 26, 2020.1 On March 10th, the Italian Ministry of Health has issue a legislative decree, effective until April 13th, 2020. The said ordinance limits the movement of individuals in the whole national territory unless due to unmovable working issues or any compelling reason which have to be proven. Universities, primary and secondary education are suspended. Any form of social interaction or cultural entertainment, including cinemas, theaters, museums, cultural centers must be shut down. Gathering in public spaces is strictly forbidden, therefore any sport event and funeral must be cancelled. Only those shops that are selling essential goods, such as supermarkets, are allowed to stay open, admitted that they can ensure a distance of at least $1.5 \mathrm{~m}$ between customers.2 Since then, I have not been out of my home.

\section{How Did Academic Institutions Respond?}

Not taking into consideration the psychological effects of this forced quarantine, which have been reported to range from post-traumatic stress symptoms to confusion and anger, one on the biggest concerns has been to ensure academic education.3 Each chancellor of the university has issued a different decree, despite some formal differences, the common rationale has been to implement online lessons and convert whenever possible written exams into orals. Oral examinations have thereafter been administered thanks to streaming platforms.4

\section{How Have Medical Schools Evolved?}

Medical school is notoriously arduous, the difficulty of medical school boils down to the breadth of subjects that are included under its banner, the almost infinite depth to which each of those subjects could be explored and the lack of clarity regarding how much knowledge of each of them is sufficient. Lectures are indeed essential for a deep understanding of the subject. The necessity of a conversion from in- class lectures to on-line ones has posed several interrogatives. For instance, the most debated question has been: "Is achievement affected when attendance is face-to-face versus online?". The said question, along with other digital scholarship related interrogatives have been analyzed by McLean et al. 5 It has been reported that it does not appear to affect student achievement whether they observe lectures live or online.

Nevertheless, my experience with online lesson has been troubled, though it is necessary to contextualize. I am a Medical student at San Raffaele University Milan, which attached to the worldwide renowned San Raffaele Hospital. Milan really is the epicenter of the COVID-19 crisis in Italy, being that it is the capital of Lombardia, the region which has been facing the most dramatic outbreak of cases. With that said, it is straightforward to understand that our lecturers, who are before everything else physician, had to overshadow teaching. Nonetheless, all faculties have tried to at least record their lessons so that we could have them available online. Unsurprisingly I have seen lectures recorded by professor still wearing coats, sometimes with scars left from face-masks and with an evidently worn-out face. Moreover, I have also had live-streaming lessons, which all in all have been considerably good. I did have faced connection issues, which are however related to the tremendous pressure posed on the internet by the almost one trillion bit per second of traffic registered in Italy as March 14, 2020.6 Likewise, many medical schools in Italy have tried to do their best to implement online lectures and, on the whole, we can affirm that medical schools have not arrested their activities.

In summary, Italy has been facing the biggest crisis, both economically and socially speaking since the end of World War II. The whole peninsula has been locked down since March 10, 2020. Universities have behaved accordingly by implementing e-learning platforms with results that are all in all satisfying, considering the issues that this situation is posing. Nevertheless, if this crisis will continue, it is necessary to improve the quality of the service provided by universities using a student-centred approach as suggested by Stodnick a Rogers in 2008.7 On March 11, 2020 the WHO declared the COVID-19 viral outbreak pandemic. 8 Therefore, more countries will have to implement e-learning strategies and Italy must be used as a benchmark. 


\section{References}

1. Istituto Superiore Sanità. Available https://www.epicentro.iss.it/coronavirus/sars-cov-2-sorveglianza-dati. updated March 26, 2020. Cited March 26, 2020.

2. Italian Ministry of Health. Available from: https://www.gazzettaufficiale.it/eli/id/2020/03/26/20A01877/sg. Last updated March 10, 2020. Cited March 26, 2020.

3. Brooks SK, Webster RK, Smith LE, Woodland L, Wessely S, Greenberg N, Rubin G]. The psychological impact of quarantine and how to reduce it: rapid review of the evidence. Lancet. 2020 Mar 14;395(10227):912-920.

4. Corriere della Sera, Coronavirus, università e didattica online (in Italian). Available from https://www.corriere.it/scuola/universita/cards/coronavirusuniversita-didattica-online-lezioni-esami-lauree-solo-distanza/lezioni-tempocovid-19_principale.shtml?refresh_ce-cp. Last updated March 5, 2020. Cited 2020 March 26.
5. Kinash S, Knight D, McLean M. Does Digital Scholarship through Online Lectures Affect Student Learning?. Educ Technol Soc. 2015;18(2):129-139.

6. Corriere della Sera, Coronavirus, mille miliardi di bit al second: un boom di connessioni (in Italian). Available from: https://www.corriere.it/economia/consumi/20_marzo_14/coronavirus-millemiliardi-dati-secondo-boom-connessioni-rischi-blackout-80fb15e4-651a-11eaac89-181bb7c2eooe.shtml. Last updated: March 14, 2020. Cited March 26, 2020.

7. Stodnick M, Rogers P. Using SERVQUAL to measure the quality of the classroom experience. Decis Sci J Innov Educ. 2008;6(1):115-133.

8. World Health Organization. Director-Ceneral's opening remarks at the media briefing on COVID-19. Available from: https://www.who.int/dg/speeches/detail/who-director-general-s-openingremarks-at-the-media-briefing-on-covid-19---11-march-2020. Last updated March 11, 2020. Cited Mar 26, 2020.

\section{Acknowledgments \\ None}

\section{Conflict of Interest Statement a Funding}

The Authors have no funding, financial relationships or conflicts of interest to disclose.

Author Contributions

Conceptualization: NGB. Methodology: NGB. Writing - Original Draft: NGB. Writing - Review \& Editing: NGB. Visualization: NGB.

Cite as:

Biavardi NG. Being an Italian Medical Student During the COVID-19 Outbreak. Int J Med Students. 2020;8(1):49-50.

This work is licensed under a Creative Commons Attribution 4.0 International License

ISSN 2076-6327

This journal is published by the University Library System, University of Pittsburgh as part of the Digital Publishing Program and is co-sponsored by the University of Pittsburgh Press. 